\title{
Bismuth(III) Complexes with Bis(dimethylphenyl) Dithiophosphates: Synthesis, Characterization and Crystal Structure of $\left[\left\{\left(3,5-\mathrm{CH}_{3}\right)_{2} \mathrm{C}_{6} \mathrm{H}_{3} \mathrm{O}\right\}_{2} \mathrm{PS}_{2}\right]_{3} \mathrm{Bi}$
}

\author{
Ruchi Khajuria, ${ }^{1}$ Sandeep Kumar, ${ }^{1}$ Mandeep Kour, ${ }^{1}$ Atiya Syed, ${ }^{1}$ \\ Geeta Hundal ${ }^{2}$ and Sushil K. Pandey ${ }^{1, *}$ \\ ${ }^{1}$ Department of Chemistry, University of Jammu, Baba Saheb Ambedkar Road, \\ Jammu-180006 ( $\mathrm{J} \& \mathrm{~K})$, India \\ ${ }^{2}$ Department of Chemistry, Guru Nanak Dev University, Amritsar-143005, India \\ *Corresponding author: E-mail: kpsushil@ rediffmail.com
}

Received: 16-05-2017

\begin{abstract}
This work presents four complexes with general formula $\left[\left\{(\mathrm{ArO})_{2} \mathrm{PS}_{2}\right\}_{3} \mathrm{Bi}\right](\mathbf{1 - 4})$, where $\mathrm{Ar}=2,4-\left(\mathrm{CH}_{3}\right)_{2} \mathrm{C}_{6} \mathrm{H}_{3}$, 2,5- $\left(\mathrm{CH}_{3}\right)_{2} \mathrm{C}_{6} \mathrm{H}_{3}, 3,4-\left(\mathrm{CH}_{3}\right)_{2} \mathrm{C}_{6} \mathrm{H}_{3}$ and 3,5- $\left(\mathrm{CH}_{3}\right)_{2} \mathrm{C}_{6} \mathrm{H}_{3}$, respectively. Reaction of $\left[(\mathrm{ArO})_{2} \mathrm{PS}_{2} \mathrm{Na}\right]$ with $\mathrm{Bi}\left(\mathrm{NO}_{3}\right)_{3} \cdot 5 \mathrm{H}_{2} \mathrm{O}$ in toluene in 3:1 molar stoichiometry afforded the complexes $\left[\left\{(\mathrm{ArO})_{2} \mathrm{PS}_{2}\right\}_{3} \mathrm{Bi}\right]$. These newly synthesized complexes have been characterized by elemental analysis, FT-IR and multinuclear NMR $\left({ }^{1} \mathrm{H},{ }^{13} \mathrm{C}\right.$ and $\left.{ }^{31} \mathrm{P}\right) \mathrm{NMR}$. The crystal structure of $\left[\left\{\left(3,5-\mathrm{CH}_{3}\right)_{2} \mathrm{C}_{6} \mathrm{H}_{3} \mathrm{O}\right\}_{2} \mathrm{PS}_{2}\right]_{3} \mathrm{Bi}(4)$ has been determined by X-ray crystallography. The compound crystallizes in monoclinic $P 2_{1} / c$ space group and $\mathrm{Bi}(\mathrm{III})$ centre is surrounded by six sulfur atoms from three symmetrically chelating bidentate diphenyl dithiophosphate ligands in a distorted octahedron environment. Screening these complexes for their antifungal activity against Pencillium chrysogenum gave positive results.
\end{abstract}

Keywords: Bi(III) Complexes; X-ray; Dithiophosphate; Fungicidal

\section{Introduction}

Dithiolates of bismuth have attracted much interest due to their diverse structural features ranging from discrete monomer to polymeric supramolecular assemblies. ${ }^{1-8}$ Low lability ${ }^{9}$ and greater thermodynamic stability ${ }^{10,11}$ of $\mathrm{Bi}-\mathrm{S}$ compounds as compared to $\mathrm{Bi}-\mathrm{O}$ compounds has resulted into their wide applicability in medicine and bio$\operatorname{logy} .{ }^{12,13}$ Due to its non-toxic and non-carcinogenic nature, the use of bismuth compounds in medicine can be traced back to the middle ages, ${ }^{14}$ although less consideration has been paid to bismuth chemistry in comparison with that of rest of the members of group 15 elements. In addition, chemistry of bismuth compounds has advanced considerably due to its potential in applications as precursors in material sciences, ${ }^{15-27}$ as X-ray imaging agents ${ }^{28}$ and as catalysts. ${ }^{29}$ Further interest in the study of these compounds lies in their significance in medicinal chemistry. The major medicinal applications of bismuth compounds are associated with the treatment of gastrointestinal disorders, antitumor, antimicrobial and antibacterial activity. ${ }^{30-36}$ Recently, with increasing environmental concerns and the need for 'green reagents', the interest in environmentally acceptable heavy metal and its compounds has increased tremendously in the last decade. The synthesis of coordination compounds with dithiophosphate ligand has been in the center of interest in chemical research for many years. ${ }^{37-43}$ Some Bi(III) complexes containing dithiophosphate ligand, such as $\left.\left[\mathrm{Bi}\left\{\mathrm{S}_{2} \mathrm{P}\left(\mathrm{OC}_{6} \mathrm{H}_{4} \mathrm{Me}-\mathrm{m}\right)_{2}\right\}_{3}\right],{ }^{44} \mathrm{Bi}\left[\mathrm{S}_{2} \mathrm{P}\left(\mathrm{i}_{-} \mathrm{C}_{3} \mathrm{H}_{7} \mathrm{O}\right)_{2}\right]\right]_{3},{ }^{45}$ have been reported previously. In addition to the above, there are myriad of bismuth compounds with short bite sulfur ligands for which $\mathrm{X}$-ray structures are known e.g. $\mathrm{Bi}\left[\mathrm{S}_{2} \mathrm{P}\left(\mathrm{C}_{6} \mathrm{H}_{5}\right)_{2}\right]_{3},{ }^{46} \mathrm{Bi}\left(\mathrm{S}_{2} \mathrm{PEt}_{2}\right)_{3} \cdot \mathrm{C}_{6} \mathrm{H}_{6},{ }^{47} \mathrm{Bi}\left(\mathrm{S}_{2} \mathrm{PMe}_{2}\right)_{3},{ }^{48}$ $\mathrm{Bi}\left[\mathrm{S}_{2} \mathrm{PEt}_{2}\right]_{3},{ }^{49} \mathrm{Bi}\left[\mathrm{S}_{2} \mathrm{COPr}^{i}\right]_{3},{ }^{50}$ and $\mathrm{Bi}\left[\mathrm{S}_{2} \mathrm{CNEt}_{2}\right]^{51}$

Bismuth, because of its large size, and the phosphorodithioate ligand, because it incorporates tetrahedral $\mathrm{S}_{2} \mathrm{PO}_{2}$ rather than planar $\mathrm{S}_{2} \mathrm{CN}$ or $\mathrm{S}_{2} \mathrm{CO}$, were considered as logical candidates suitable for study. In the above perceptive it was considered worthwhile to prepare similar new dithiophosphate complexes and to study their structu- 
ral features with an aim of identifying new structural motifs. In the present communication, we describe the syntheses of a new mononuclear bismuth(III) complexes containing the disubstituted diphenyl dithiophosphate ligand. In addition, the structure of the complex $\mathbf{4}$ has been determined by $\mathrm{X}$-ray diffraction. In addition to the physico-chemical studies, the compounds 1-4 have also been tested in vitro to assess their antifungal activities against common reference fungai, and the results were compared with similar doses of commercial antibiotic, namely ciprofloxacin.

\section{Experimental}

\section{1. Reagents, Materials and Measurements}

Owing to extremely hydrolysable nature of the starting materials as well as the newly synthesized compounds, stringent precautions were taken to exclude atmospheric moisture throughout all the experimental manipulations. All chemicals were procured from Aldrich. Solvents were freshly distilled according to standard procedures. The characterization of the novel bismuth complexes has been done by elemental analyses, FTIR and NMR spectroscopy. C, $\mathrm{H}$ and $\mathrm{S}$ microanalysis were obtained with a CHNS/O Vario EL-III full-automatic Elemental Analyser (Indian Institute of Integrative Medicine, Jam$\mathrm{mu}$ ). Bismuth was estimated gravimetrically as BiOI. ${ }^{52}$ The infrared spectra were recorded on a Perkin Elmerspectrum RX1 FT-IR spectrophotometer (Sophisticated Analytical Instrumentation Facility, Panjab University, Chandigarh) using $\mathrm{KBr}$ discs. ${ }^{1} \mathrm{H}$ and ${ }^{13} \mathrm{C}\left\{{ }^{1} \mathrm{H}\right\}$ NMR in solution were recorded on a Bruker Avance III $400 \mathrm{MHz} .{ }^{1} \mathrm{H}$ and ${ }^{13} \mathrm{C}$ NMR spectra of the complexes were measured in $\mathrm{CDCl}_{3}$ solution with reference to an internal TMS. All chemical shifts are reported in $\delta$ units downfield from $\mathrm{Me}_{4} \mathrm{Si} .{ }^{31} \mathrm{P}\left\{{ }^{1} \mathrm{H}\right\}$ NMR spectra were run, relative to external $\mathrm{H}_{3} \mathrm{PO}_{4}(85 \%)$, with a Bruker Avance III $400 \mathrm{MHz}$. NMR Spectral was carried out at the Department of Chemistry, University of Jammu, Jammu. The sodium salts of disubstituted $O, O$ '-diphenyldithiophosphates i.e. $\{(2,4-$ $\left.\left.\mathrm{CH}_{3}\right)_{2} \mathrm{C}_{6} \mathrm{H}_{3} \mathrm{O}\right\}_{2} \mathrm{PS}_{2} \mathrm{Na}(\mathbf{L 1}),\left\{\left(2,5-\mathrm{CH}_{3}\right)_{2} \mathrm{C}_{6} \mathrm{H}_{3} \mathrm{O}\right\}_{2} \mathrm{PS}_{2} \mathrm{Na}$ (L2), $\left\{\left(3,4-\mathrm{CH}_{3}\right)_{2} \mathrm{C}_{6} \mathrm{H}_{3} \mathrm{O}_{2} \mathrm{PS}_{2} \mathrm{Na} \quad(\mathbf{L 3})\right.$ and $\{(3,5-$ $\left.\mathrm{CH}_{3}\right)_{2} \mathrm{C}_{6} \mathrm{H}_{3} \mathrm{O}_{2} \mathrm{PS}_{2} \mathrm{Na}(\mathbf{L 4})$ were synthesized following a previously reported procedure. ${ }^{37}$

\section{2. Synthesis of $\left[\left\{\left(2,4-\mathrm{CH}_{3}\right)_{2} \mathrm{C}_{6} \mathrm{H}_{3} \mathrm{O}\right\}_{2} \mathrm{PS}_{2}\right]_{3}$ Bi (1)}

The bismuth complex was prepared by adding toluene suspension $(25 \mathrm{~mL})$ of the ligand $\mathbf{L 1}(1.00 \mathrm{~g}, 2.77$ mmol) to the weighed amount of $\mathrm{Bi}\left(\mathrm{NO}_{3}\right)_{3} \cdot 5 \mathrm{H}_{2} \mathrm{O}(0.44 \mathrm{~g}$, $0.90 \mathrm{mmol})$ in toluene $(25 \mathrm{~mL})$ while stirring continuously at room temperature for 4 hours during which the solution color changes to yellow. Excess of solvent was removed by filtration using an alkoxy funnel fitted with a
G-4 disc under reduced pressure, which resulted in the complex 1 as a yellow crystalline solid. Yield: $0.99 \mathrm{~g}$ (90\%). FTIR $\left(\mathrm{KBr}, \mathrm{cm}^{-1}\right): 1117 \mathrm{~s}[v(\mathrm{P})-\mathrm{O}-\mathrm{C}], 870 \mathrm{~s}$ $[v \mathrm{P}-\mathrm{O}-(\mathrm{C})], 673 \mathrm{~s}[v \mathrm{P}-\mathrm{S}]_{\text {asym }}, 580 \mathrm{~m}[v \mathrm{P}-\mathrm{S}]_{\text {sym }}, 256 \mathrm{w}$ [ $v \mathrm{Bi}-\mathrm{S}] .{ }^{1} \mathrm{H}$ NMR $\left(\mathrm{CDCl}_{3}, \mathrm{ppm}\right): 2.30\left(\mathrm{~s}, 18 \mathrm{H}, 2-\mathrm{CH}_{3}\right)$, $2.39\left(\mathrm{~s}, 18 \mathrm{H}, 4-\mathrm{CH}_{3}\right), 6.89\left(\mathrm{~d}, J_{\mathrm{HH}}=8 \mathrm{~Hz}, 6 \mathrm{H}, \mathrm{H}_{6}\right), 7.02$ $\left(\mathrm{d}, J_{\mathrm{HH}}=8 \mathrm{~Hz}, 6 \mathrm{H}, \mathrm{H}_{5}\right), 7.22\left(\mathrm{~s}, 6 \mathrm{H}, \mathrm{H}_{3}\right) ;{ }^{13} \mathrm{C} \mathrm{NMR}(\mathrm{CDC}-$ $\left.\mathrm{l}_{3}, \mathrm{ppm}\right): 17.27\left(\mathrm{~s}, 2-\mathrm{CH}_{3}\right), 21.49\left(\mathrm{~s}, 4-\mathrm{CH}_{3}\right), 121.05\left(\mathrm{C}_{6}\right)$, $127.28\left(\mathrm{C}_{2}-\mathrm{CH}_{3}\right), 128.25\left(\mathrm{C}_{5}\right), 129.06\left(\mathrm{C}_{4}-\mathrm{CH}_{3}\right), 130.22$ $\left(\mathrm{C}_{3}\right), 147.20\left(\mathrm{C}_{1}-\mathrm{O}\right) ;{ }^{31} \mathrm{P} \mathrm{NMR}\left(\mathrm{CDCl}_{3}, \mathrm{ppm}\right): 94.15$ (s). Anal. Calcd. for $\mathrm{C}_{48} \mathrm{H}_{54} \mathrm{P}_{3} \mathrm{~S}_{6} \mathrm{O}_{6} \mathrm{Bi}$ : C, 47.21; H, 4.46; S, $15.75 ; \mathrm{Bi}, 17.11 \%$. Found: C, 47.19; H, 4.43; S, 15.70; Bi, $16.97 \%$.

\section{3. Synthesis of $\left[\left\{\left(2,5-\mathrm{CH}_{3}\right)_{2} \mathrm{C}_{6} \mathrm{H}_{3} \mathrm{O}\right\}_{2} \mathrm{PS}_{2}\right]_{3}$ Bi (2)}

The same synthetic procedure as for complex 1 was used for complex 2, except that ligand $\mathbf{L 2}(1.00 \mathrm{~g}, 2.77$ mmol) was used instead of L1. Yield: $1.01 \mathrm{~g} \mathrm{(92 \% ).} \mathrm{FTIR}$ $\left(\mathrm{KBr}, \mathrm{cm}^{-1}\right): 1024 \mathrm{~s}[v(\mathrm{P})-\mathrm{O}-\mathrm{C}], 855 \mathrm{~s}[v \mathrm{P}-\mathrm{O}-(\mathrm{C})], 682 \mathrm{~s}$ $[v \mathrm{P}-\mathrm{S}]_{\text {asym }}, 562 \mathrm{~m}[v \mathrm{P}-\mathrm{S}]_{\text {sym }}, 255 \mathrm{w}[v \mathrm{Bi}-\mathrm{S}] .{ }^{1} \mathrm{H}$ NMR $\left(\mathrm{CDCl}_{3}, \mathrm{ppm}\right): 2.31\left(\mathrm{~s}, 18 \mathrm{H}, 2-\mathrm{CH}_{3}\right), 2.34(\mathrm{~s}, 18 \mathrm{H}$, $\left.5-\mathrm{CH}_{3}\right), 7.23\left(\mathrm{~d}, J_{\mathrm{HH}}=7.6 \mathrm{~Hz}, 6 \mathrm{H}, \mathrm{H}_{3}\right), 7.16\left(\mathrm{~d}, J_{\mathrm{HH}}=7.6\right.$ $\left.\mathrm{Hz}, 6 \mathrm{H}, \mathrm{H}_{4}\right), 6.49\left(\mathrm{~s}, 6 \mathrm{H}, \mathrm{H}_{6}\right) ;{ }^{13} \mathrm{C} \mathrm{NMR}\left(\mathrm{CDCl}_{3}, \mathrm{ppm}\right)$ : $15.03\left(\mathrm{~s}, 2-\mathrm{CH}_{3}\right), 21.21\left(\mathrm{~s}, 5-\mathrm{CH}_{3}\right), 120.38\left(\mathrm{C}_{6}\right), 120.98$ $\left(\mathrm{C}_{4}\right), 128.04\left(\mathrm{C}_{2}-\mathrm{CH}_{3}\right), 130.74\left(\mathrm{C}_{3}\right), 134.75\left(\mathrm{C}_{5}-\mathrm{CH}_{3}\right)$, $155.93\left(\mathrm{C}_{1}-\mathrm{O}\right) ;{ }^{31} \mathrm{P}$ NMR $\left(\mathrm{CDCl}_{3}, \mathrm{ppm}\right)$ : 94.36 (s). Anal. Calcd. for $\mathrm{C}_{48} \mathrm{H}_{54} \mathrm{P}_{3} \mathrm{~S}_{6} \mathrm{O}_{6} \mathrm{Bi}$ : C, 47.21; H, 4.46; $\mathrm{S}, 15.75 ; \mathrm{Bi}$, $17.11 \%$. Found: C, 47.17; H, 4.39; S, 15.72; Bi, $16.95 \%$.

\section{4. Synthesis of $\left[\left\{\left(3,4-\mathrm{CH}_{3}\right)_{2} \mathrm{C}_{6} \mathrm{H}_{3} \mathrm{O}\right\}_{2} \mathrm{PS}_{2}\right]_{3}$ Bi (3)}

The same synthetic procedure as for complex 1 was used for complex 3, except that ligand $\mathbf{L 3}$ (1.00 g, 2.77 mmol) was used instead of L1. Yield: $1.03 \mathrm{~g}(94 \%)$. FTIR $\left(\mathrm{KBr}, \mathrm{cm}^{-1}\right): 1141 \mathrm{~s}[v(\mathrm{P})-\mathrm{O}-\mathrm{C}], 843 \mathrm{~s}[v \mathrm{P}-\mathrm{O}-(\mathrm{C})], 683 \mathrm{~s}$ $[v \mathrm{P}-\mathrm{S}]_{\text {asym }}, 578 \mathrm{~m}[v \mathrm{P}-\mathrm{S}]_{\text {sym }}, 246 \mathrm{w}[v \mathrm{Bi}-\mathrm{S}] .{ }^{1} \mathrm{H}$ NMR $\left(\mathrm{CDCl}_{3}, \mathrm{ppm}\right): 2.49\left(\mathrm{~s}, 18 \mathrm{H}, 4-\mathrm{CH}_{3}\right), 2.65(\mathrm{~s}, 18 \mathrm{H}$, $\left.3-\mathrm{CH}_{3}\right), 7.35\left(\mathrm{~d}, J_{\mathrm{HH}}=7.6 \mathrm{~Hz}, 6 \mathrm{H}, \mathrm{H}_{6}\right), 7.48\left(\mathrm{~s}, 6 \mathrm{H}, \mathrm{H}_{2}\right)$, $7.55\left(\mathrm{~d}, J_{\mathrm{HH}}=8 \mathrm{~Hz}, 6 \mathrm{H}, \mathrm{H}_{5}\right) ;{ }^{13} \mathrm{C} \mathrm{NMR}\left(\mathrm{CDCl}_{3}, \mathrm{ppm}\right)$ : $19.45\left(\mathrm{~s}, 4-\mathrm{CH}_{3}\right), 21.79\left(\mathrm{~s}, 3-\mathrm{CH}_{3}\right), 150.46\left(\mathrm{C}_{6}\right), 122.88$ $\left(\mathrm{C}_{2}\right), 130.67\left(\mathrm{C}_{4}-\mathrm{CH}_{3}\right), 134.27\left(\mathrm{C}_{5}\right), 138.31\left(\mathrm{C}_{3}-\mathrm{CH}_{3}\right)$, $148.96\left(\mathrm{C}_{1}-\mathrm{O}\right) ;{ }^{31} \mathrm{P}$ NMR $\left(\mathrm{CDCl}_{3}, \mathrm{ppm}\right): 95.03$ (s). Anal. Calcd. for $\mathrm{C}_{48} \mathrm{H}_{54} \mathrm{P}_{3} \mathrm{~S}_{6} \mathrm{O}_{6} \mathrm{Bi}$ : C, 47.21; H, 4.46; S, 15.75; $\mathrm{Bi}, 17.11 \%$. Found: C, 47.19; H, 4.40; S, 15.72; Bi, $16.94 \%$.

\section{5. Synthesis of $\left[\left\{\left(3,5-\mathrm{CH}_{3}\right)_{2} \mathrm{C}_{6} \mathrm{H}_{3} \mathrm{O}\right\}_{2} \mathrm{PS}_{2}\right]_{3}$ Bi (4)}

The same synthetic procedure as for complex $\mathbf{1}$ was used for complex 4, except that ligand L4 (1.00 g, 2.77 mmol) was used instead of L1. Yield: $1.04 \mathrm{~g}(95 \%)$. FTIR $\left(\mathrm{KBr}, \mathrm{cm}^{-1}\right): 1128 \mathrm{~s}[v(\mathrm{P})-\mathrm{O}-\mathrm{C}], 834 \mathrm{~s}[v \mathrm{P}-\mathrm{O}-(\mathrm{C})], 682 \mathrm{~s}$ 
$[v \mathrm{P}-\mathrm{S}]_{\text {asym }}, 564 \mathrm{~m}[v \mathrm{P}-\mathrm{S}]_{\text {sym }}, 256 \mathrm{w}[v \mathrm{Bi}-\mathrm{S}] .{ }^{1} \mathrm{H}$ NMR $\left(\mathrm{CDCl}_{3}, \mathrm{ppm}\right): 2.35\left(\mathrm{~s}, 36 \mathrm{H}, 3,5-\left(\mathrm{CH}_{3}\right)_{2}\right), 6.84(\mathrm{~s}, 12 \mathrm{H}$, $\left.\mathrm{H}_{2}, 6\right), 6.92\left(\mathrm{~s}, 6 \mathrm{H}, \mathrm{H}_{4}\right) ;{ }^{13} \mathrm{C} \mathrm{NMR}\left(\mathrm{CDCl}_{3}, \mathrm{ppm}\right): 21.26$ (s, $\left.3,5-\left(\mathrm{CH}_{3}\right)_{2}\right), 119.16\left(\mathrm{C}_{2,6}\right), 127.49\left(\mathrm{C}_{4}\right), 139.41\left(\mathrm{C}_{3,5}-\mathrm{CH}_{3}\right)$, $150.50\left(\mathrm{C}_{1}-\mathrm{O}\right) ;{ }^{31} \mathrm{P}$ NMR $\left(\mathrm{CDCl}_{3}, \mathrm{ppm}\right): 93.30$ (s). Anal. Calcd. for $\mathrm{C}_{48} \mathrm{H}_{54} \mathrm{P}_{3} \mathrm{~S}_{6} \mathrm{O}_{6} \mathrm{Bi}: \mathrm{C}, 47.21 ; \mathrm{H}, 4.46 ; \mathrm{S}, 15.75$; $\mathrm{Bi}$, $17.11 \%$. Found: C, 47.20; H, 4.42; S, 15.74; Bi, $17.05 \%$.

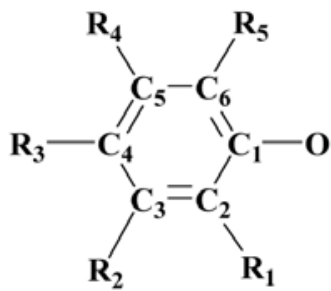

1. $\mathbf{R}_{1}=\mathrm{CH}_{3}, \mathbf{R}_{\mathbf{2}}=\mathrm{H}_{3}, \mathbf{R}_{\mathbf{3}}=\mathrm{CH}_{3}, \mathbf{R}_{\mathbf{4}}=\mathrm{H}_{5}, \mathbf{R}_{\mathbf{5}}=\mathrm{H}_{6}$

2. $\mathbf{R}_{\mathbf{1}}=\mathrm{CH}_{3}, \mathbf{R}_{\mathbf{2}}=\mathrm{H}_{3}, \mathbf{R}_{\mathbf{3}}=\mathrm{H}_{4}, \mathbf{R}_{\mathbf{4}}=\mathrm{CH}_{3}, \mathbf{R}_{\mathbf{5}}=\mathrm{H}_{6}$

3. $\mathbf{R}_{1}=\mathrm{H}_{2}, \mathbf{R}_{\mathbf{2}}=\mathrm{CH}_{3}, \mathbf{R}_{\mathbf{3}}=\mathrm{CH}_{3}, \mathbf{R}_{\mathbf{4}}=\mathrm{H}_{5}, \mathbf{R}_{\mathbf{5}}=\mathrm{H}_{6}$

4. $\mathbf{R}_{\mathbf{1}}=\mathrm{H}_{2}, \mathbf{R}_{\mathbf{2}}=\mathrm{CH}_{3}, \mathbf{R}_{\mathbf{3}}=\mathrm{H}_{4}, \mathbf{R}_{\mathbf{4}}=\mathrm{CH}_{3}, \mathbf{R}_{\mathbf{5}}=\mathrm{H}_{6}$

Scheme 1. Ring labelling for NMR spectroscopic assignments of complexes 1-4.

\section{6. Antifungal Activity}

Agar well diffusion method ${ }^{53}$ was used for screening the in vitro antifungal studies of these complexes. The compounds were dissolved in dimethyl sulfoxide (DM$\mathrm{SO})$. Further progressive dilutions were performed to obtain the required concentrations $100 \mathrm{ppm}, 500 \mathrm{ppm}$ and $1000 \mathrm{ppm}$. Using a sterile cork borer (6 $\mathrm{mm}$ in diameter), three holes were made in each dish and then $0.1 \mathrm{~mL}$ of the tested compound dissolved in DMSO (100 ppm, 500 ppm, 1000 ppm) was added into these holes. Finally, the petri dishes were incubated at $27^{\circ} \mathrm{C}$ for $48 \mathrm{~h}$. Distinct or light inhibition zones were observed, around each hole, which were measured in millimetres as the diameter of inhibition zones and solvent DMSO exhibited (zone of inhibition) on the organism tested.

\section{7. Crystallography Data Collection and Refinement}

Suitable yellow colored and prism shaped singlecrystals of complex $\mathbf{4}$ for X-ray analysis were obtained by keeping its saturated solution in toluene at low temperature for some hours. For X-ray diffraction studies suitable single-crystal of complex $\mathbf{4}$ was mounted on a Bruker Apex-II CCD diffractometer (Department of Chemistry, Guru Nanak Dev University, Amritsar) equipped with graphite monochromated $\operatorname{Mo~} \mathrm{K} \alpha(\lambda=0.71069 \AA)$ at room temperature. The data collected at room temperature were processed and corrected for absorption using SIR-92 software and refined by full-matrix least-squares refinement methods based on $F^{2}$, using the program SHELXL97. The reflection data were collected and processed by SAINT

Table 1. Crystal data and structure refinements for $[\{(3,5-$ $\left.\left.\left.\mathrm{CH}_{3}\right)_{2} \mathrm{C}_{6} \mathrm{H}_{3} \mathrm{O}\right\}_{2} \mathrm{PS}_{2}\right]_{3} \mathrm{Bi}(4)$.

\begin{tabular}{ll}
\hline Chemical formula & $\mathrm{C}_{48} \mathrm{H}_{54} \mathrm{BiO}_{6} \mathrm{P}_{3} \mathrm{~S}_{6}$ \\
CCDC & 1547047 \\
$M_{\mathrm{r}}$ & 1221.23 \\
Crystal system, space group & Monoclinic, $P 2_{1} / c$ \\
$T(\mathrm{~K})$ & 296 \\
$a, b, c(\AA)$ & $13.076(1), 21.6280$ \\
$\beta\left({ }^{\circ}\right)$ & $(14), 19.3220(13)$ \\
$V\left(\AA^{3}\right)$ & $96.302(3)$ \\
$Z$ & $5431.4(7)$ \\
$\mu\left(\mathrm{mm}^{-1}\right)$ & 4 \\
No. of reflections & 3.61 \\
No. of observed $[I>2 \sigma(I)]$ & 10867 \\
reflections & 7639 \\
No. of parameters & \\
$R_{\text {int }}$ & 589 \\
$R\left[F^{2}>2 \sigma\left(F^{2}\right)\right], w R\left(F^{2}\right), S$ & 0.069 \\
$\Delta \rho_{\max }, \Delta \rho_{\min }\left(\mathrm{e} \AA^{-3}\right)$ & $0.038,0.080,0.98$ \\
\hline
\end{tabular}

correcting for Lorentz and polarization effects. An empirical absorption correction was applied using SADABS from Bruker. All non-hydrogen atoms were refined anisotropically. All calculations were performed using Wingx package. Molecular drawings were obtained using DIAMOND version 2.1. Crystallographic data and refinement details for the compound $\mathbf{4}$ are summarized in Table 1.

\section{Results and Discussion}

The complexes were obtained as stable compounds at room temperature by the reaction of bismuth nitrate pentahydrate with $O, O^{\prime}$-bis(disubstitutedphenyl)phosphorodithioate in a 1:3 stoichiometric ratio in toluene at room

$$
\begin{aligned}
& 3(\mathrm{ArO})_{2} \mathrm{PS}_{2} \mathrm{Na} \quad+\quad \mathrm{Bi}\left(\mathrm{NO}_{3}\right)_{3} \cdot 5 \mathrm{H}_{2} \mathrm{O} \longrightarrow \text { Toluene } \longrightarrow\left[\left\{(\mathrm{ArO})_{2} \mathrm{PS}_{2}\right\}_{3} \mathrm{Bi}\right] \\
& \text { Stirring } 4 \text { hrs } \\
& -3 \mathrm{NaNO}_{3}
\end{aligned}
$$$$
\mathrm{Ar}=2,4-\left(\mathrm{CH}_{3}\right)_{2} \mathrm{C}_{6} \mathrm{H}_{3}(\mathbf{1}), 2,5-\left(\mathrm{CH}_{3}\right)_{2} \mathrm{C}_{6} \mathrm{H}_{3}(2), 3,4-\left(\mathrm{CH}_{3}\right)_{2} \mathrm{C}_{6} \mathrm{H}_{3}(3) \text { and 3,5- }\left(\mathrm{CH}_{3}\right)_{2} \mathrm{C}_{6} \mathrm{H}_{3}
$$

Scheme 2. Preparation of the complexes 1-4. 
temperature. In order to confirm the chemical composition of the synthesized complexes, X-ray, FT-IR, and ${ }^{1} \mathrm{H}$, ${ }^{13} \mathrm{C}$ and ${ }^{31} \mathrm{P}$ NMR analyses were carried out with results are presented in the experimental section. The scheme for the formation of the complexes is as follows:

\section{1. Spectroscopic Analysis}

The main infrared vibration bands are reported in the experimental section. The FTIR spectra of the complexes and the ligand were compared and assigned on careful comparison. One important band which confirms the bismuth to sulfur bonding $v(\mathrm{Bi}-\mathrm{S})$ has been observed as a weak signal at $246-256 \mathrm{~cm}^{-1}$. In addition, the spectrum of the complexes shows a strong band at $1141-1024 \mathrm{~cm}^{-1}$ and $870-834 \mathrm{~cm}^{-1}$ due to the $[\mathrm{v}(\mathrm{P})-\mathrm{O}-\mathrm{C}]$ and $[\mathrm{vP}-\mathrm{O}-(\mathrm{C})]$ stretching vibrations. The most identifiable IR absorptions for complexes 1-4 are $683-673 \mathrm{~cm}^{-1}$ and $580-562 \mathrm{~cm}^{-1}$, assigned to $[\mathrm{vP}-\mathrm{S}]_{\text {asym }}$ and $[\mathrm{vP}-\mathrm{S}]_{\text {sym }}$ respectively. These bands are shifted to lower frequency as compared to the free ligand. It is found that the coordination mode of the dithiophosphate ligand is bidentate by the sulfur atoms. This is also consistent with the crystal structure of the complex.

The ${ }^{1} \mathrm{H}$ NMR spectra of bismuth(III) dithiophosphate complexes were recorded in $\mathrm{CDCl}_{3}$ with tetramethylsilane as an internal standard and are reported in experimental section. The spectra show the characteristic resonance for methyl and aromatic protons. In the complexes 1-4, chemical shift for $-\mathrm{CH}_{3}$ protons attached to aryl appears at $2.30-2.65 \mathrm{ppm}$ as a singlet. The chemical shifts for the aryl ring protons were observed in the region $6.49-7.55 \mathrm{ppm}$ with their usual splitting pattern. ${ }^{37,38}$

In the ${ }^{13} \mathrm{C}\left\{{ }^{1} \mathrm{H}\right\}$ NMR spectra of these complexes, the chemical shift for methyl carbon $\left(-\mathrm{CH}_{3}\right)$ attached to the aryl ring was observed in the region 15.03-21.79 ppm. The carbon nuclei of the phenyl group have displayed their resonance in the region 119.16-155.93 ppm.

${ }^{31} \mathrm{P}\left\{{ }^{1} \mathrm{H}\right\}$ NMR spectra showed only one sharp resonance signal at $93.30-95.03 \mathrm{ppm}$ in the upfield region compared to that of the free ligand (106.5-107.4 ppm) with a difference of $13 \mathrm{ppm}$, which indicates a considerable drift of electron density from the phosphorus to the metal atom through both sulfur atoms and thus confirms the formation of a chelated structure with a bidentate $O, O^{\prime}$-diphenyl dithiophosphate. This range observed for ${ }^{31} \mathrm{P}$ NMR in these complexes may be correlated with bidentate behavior of the dithiophosphate moiety. ${ }^{54}$

\section{2. Molecular and Crystal Structure of 4}

In order to understand the structural details, single crystal X-ray diffraction study of compound $\mathbf{4}$ was performed. Complex 4 crystallizes in the monoclinic $P 2_{1} / c$ space group. ORTEP view of the molecular structure of $\mathbf{4}$ with atom numbering scheme is given in Figure 1.

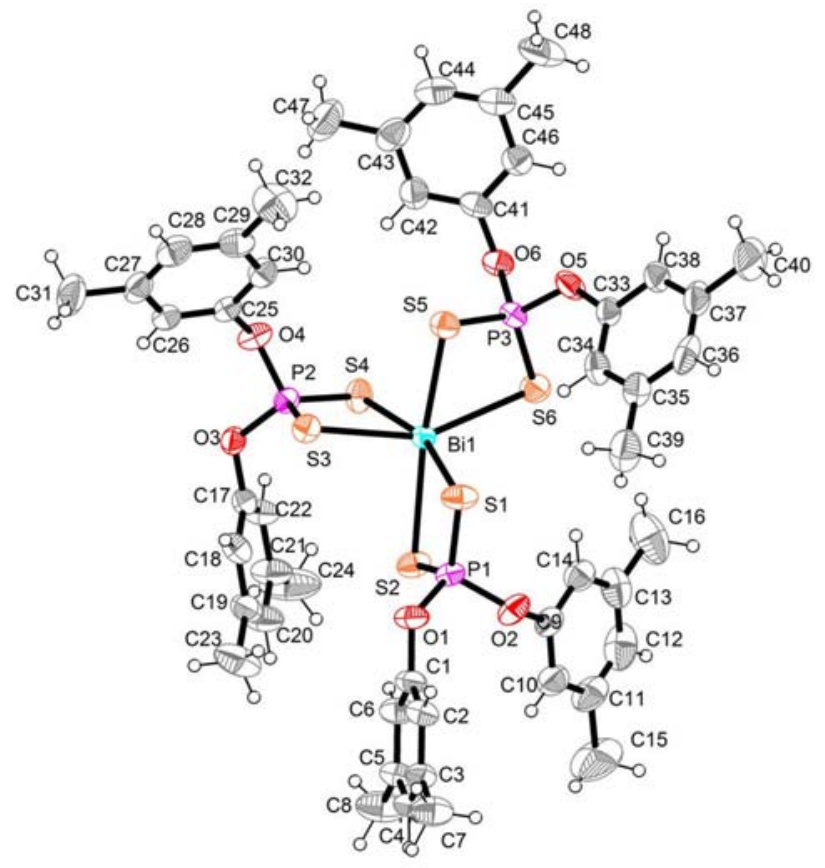

Fig. 1: ORTEP view of $\left[\left\{\left(3,5-\mathrm{CH}_{3}\right)_{2} \mathrm{C}_{6} \mathrm{H}_{3} \mathrm{O}\right\}_{2} \mathrm{PS}_{2}\right]_{3} \mathrm{Bi}(4)$.

The molecule consists of neutral well separated monomeric units. The ligands are bidentate but the attachment of each dithiophosphato moiety to bismuth is slightly unsymmetrical with one short $(2.6926(12)$ to 2.7884(12) Å) and one long (2.7794(12) to 2.9162(13) A) $\mathrm{Bi}-\mathrm{S}$ bond forming distorted octahedral geometry. Due to three short and three long $\mathrm{Bi}-\mathrm{S}$ bond, the configuration is approximately $C_{3 v}$. These ranges are consistent with typical values reported for the short and long ligand bond in $\left[\mathrm{Bi}\left\{\mathrm{S}_{2} \mathrm{P}\left(\mathrm{OC}_{6} \mathrm{H}_{4} \mathrm{Me}-\mathrm{m}\right)_{2}\right\}\right]_{3}(2.678(2) \text { to } 2.953(2) \AA)^{44}$, $\left[\mathrm{Bi}\left\{\mathrm{S}_{2} \mathrm{P}(\mathrm{OEt})_{2}\right\}_{3}\right] \quad(2.747(14) \text { to } 2.795(12) \AA)^{55}$ and $\left[\mathrm{Bi}\left\{\mathrm{S}_{2} \mathrm{P}\{\mathrm{O}(\mathrm{i}-\mathrm{Pr})\}_{2}\right\}_{3}\right]\left(2.702(6)\right.$ to $2.8784(6) \AA^{45}$.

Asymmetrical coordination necessarily leads to an inverse relationship between the $\mathrm{Bi}-\mathrm{S}$ and related $\mathrm{P}-\mathrm{S}$ bond lengths. $\mathrm{P}_{1}-\mathrm{S}_{1}$ and $\mathrm{P}_{2}-\mathrm{S}_{2}$ bond length in $4\left[\mathrm{P}_{1}-\mathrm{S}_{1}=\right.$ 1.9807(17) and $\mathrm{P}_{1}-\mathrm{S}_{2}=1.9727$ (17) $\AA$ ] are intermediate between single $(2.14 \AA)$ and double (1.94 $\AA$ ) P-S bonds, suggesting the negative charge is delocalized over the S-P-S fragment. The shorter P-S (1.9727(17) $\AA$ ) is associated with sulfur atoms forming the longer $\mathrm{Bi}-\mathrm{S}$ interaction $(2.8457(13) \AA$ ) while the longer $\mathrm{P}-\mathrm{S}$ bond (1.9807(17) $\AA$ ) is allied with the sulfur atoms forming the shorter bonds to the bismuth (2.7884(12) $\AA$ ).

The $\mathrm{S}-\mathrm{Bi}-\mathrm{S}$ bite angle in 4 cover a wide range of $88.6(4)$ to $92.73(4)^{\circ}$. The interligand angles involving the longer $\mathrm{Bi}-\mathrm{S}$ bonds are considerably larger ranging from $88.86(4)$ to $110.64(4)^{\circ}$.

\section{3. Antifungal Activity}

Antifungal activities of free ligands, metal salt $\mathrm{Bi}\left(\mathrm{NO}_{3}\right)_{3} \cdot 5 \mathrm{H}_{2} \mathrm{O}$ and synthesized compounds have been 
Table 2. Selected bond lengths $(\AA)$ and angles $\left(^{\circ}\right)$ for $[\{(3,5-$ $\left.\left.\left.\mathrm{CH}_{3}\right)_{2} \mathrm{C}_{6} \mathrm{H}_{3} \mathrm{O}\right\}_{2} \mathrm{PS}_{2}\right]_{3} \mathrm{Bi}(4)$

\begin{tabular}{lllr}
\hline O1-P1 & $1.584(3)$ & P2-S3 & $1.9967(16)$ \\
O2-P1 & $1.592(3)$ & P3-S6 & $1.9562(18)$ \\
O3-P2 & $1.586(3)$ & P3-S5 & $1.9931(17)$ \\
O4-P2 & $1.566(3)$ & S1-Bi1 & $2.7884(12)$ \\
O5-P3 & $1.582(3)$ & S2-Bi1 & $2.8457(13)$ \\
O6-P3 & $1.579(3)$ & S3-Bi1 & $2.6926(12)$ \\
P1-S2 & $1.9727(17)$ & S4-Bi1 & $2.7794(12)$ \\
P1-S1 & $1.9807(17)$ & S5-Bi1 & $2.7347(12)$ \\
P2-S4 & $1.9755(17)$ & S6-Bi1 & $2.9162(13)$ \\
\hline O1-P1-O2 & $101.13(17)$ & P2-S3-Bi1 & $86.97(5)$ \\
O1-P1-S2 & $113.19(14)$ & P2-S4-Bi1 & $84.99(5)$ \\
O2-P1-S2 & $112.00(14)$ & P3-S5-Bi1 & $87.76(6)$ \\
O1-P1-S1 & $104.89(14)$ & P3-S6-Bi1 & $83.43(6)$ \\
O2-P1-S1 & $110.14(15)$ & S3-Bi1-S5 & $88.68(4)$ \\
S2-P1-S1 & $114.49(8)$ & S3-Bi1-S4 & $74.67(4)$ \\
O4-P2-O3 & $100.22(17)$ & S5-Bi1-S4 & $97.02(4)$ \\
O4-P2-S4 & $108.09(14)$ & S3-Bi1-S1 & $92.82(4)$ \\
O3-P2-S4 & $112.56(13)$ & S5-Bi1-S1 & $92.17(4)$ \\
O4-P2-S3 & $111.82(13)$ & S4-Bi1-S1 & $164.23(4)$ \\
O3-P2-S3 & $110.04(13)$ & S3-Bi1-S2 & $92.73(4)$ \\
S4-P2-S3 & $113.37(7)$ & S5-Bi1-S2 & $164.47(4)$ \\
O6-P3-O5 & $99.74(16)$ & S4-Bi1-S2 & $98.27(4)$ \\
O6-P3-S6 & $107.88(14)$ & S1-Bi1-S2 & $72.32(4)$ \\
O5-P3-S6 & $112.63(15)$ & S3-Bi1-S6 & $153.29(4)$ \\
O6-P3-S5 & $110.40(13)$ & S5-Bi1-S6 & $72.33(4)$ \\
O5-P3-S5 & $109.66(15)$ & S4-Bi1-S6 & $88.86(4)$ \\
S6-P3-S5 & $115.38(8)$ & S1-Bi1-S6 & $106.19(4)$ \\
P1-S1-Bi1 & $87.01(5)$ & S2-Bi1-S6 & $110.64(4)$ \\
P1-S2-Bi1 & $85.57(5)$ & & \\
\hline & & & \\
\hline
\end{tabular}

examined at four different concentrations $100 \mathrm{ppm}, 500$ ppm and 1000 ppm against fungus Penicillium chrysogenum. Obtained results have been compared with the standard drug. We conclude that sulfur donor bismuth complexes inhibit the growth of fungi to a greater extent, as concentration is increased. All the results are summarized in Table 3. The results have been obtained as follows:

1. The ligands L1, L2, L3 and $\mathbf{L 4}$ showed a negligible inhibitory effect compared to the complexes.

2. Complexes exhibit higher antifungal activities than the corresponding free ligands due to the chelation of the ligand with bismuth.

3. On increasing the concentration of the complex, antifungal activity increases.

4. The increase in antifungal activity might be due to faster diffusion of the complexes as a whole through the cell membrane, or due to a combined activity effect of the metal and the ligand. The polarity of the metal ion will be reduced to a greater extent due to the overlap of the ligand orbitals.

The illustrated comparative results of antifungal analysis are given graphically in Figure 2 .

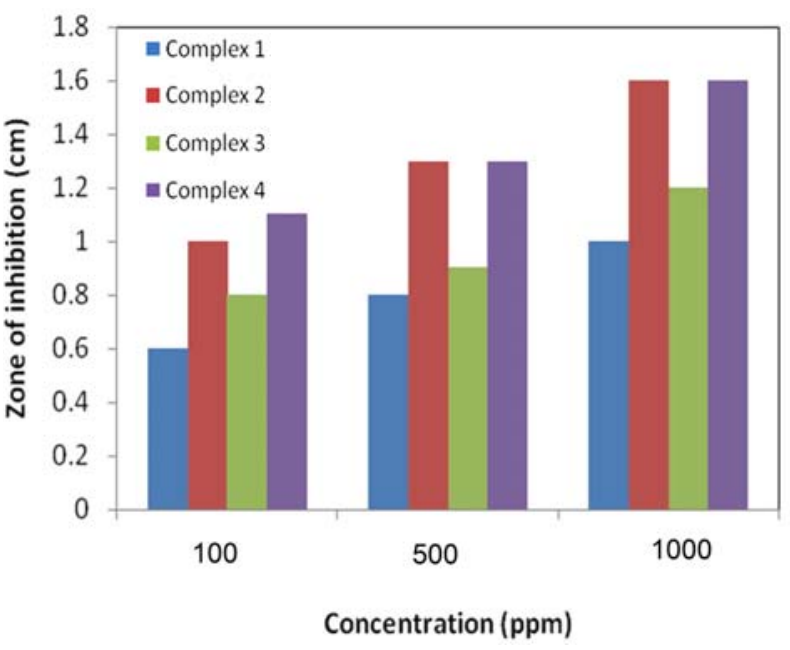

Fig. 2: Comparative results of antifungal screening data.

Table 3. Antifungal activity of diphenyl dithiophosphate ligands and bismuth(III) complexes against the fungus Penicillium chrysogenum.

\begin{tabular}{|c|c|c|}
\hline S.No. & $\begin{array}{c}\text { Concentration } \\
(\mathbf{p p m})\end{array}$ & $\begin{array}{c}\text { Zone } \\
\text { of inhibition } \\
(\mathrm{cm})\end{array}$ \\
\hline \multirow{3}{*}{$\left(2,4-\left(\mathrm{CH}_{3}\right)_{2} \mathrm{C}_{6} \mathrm{H}_{3} \mathrm{O}\right)_{2} \mathrm{PS}_{2}$} $\mathrm{Na}(\mathbf{L 1})$ & 100 & 0.0 \\
\hline & 500 & 0.0 \\
\hline & 1000 & 0.0 \\
\hline \multirow{3}{*}{$\left(2,5-\left(\mathrm{CH}_{3}\right)_{2} \mathrm{C}_{6} \mathrm{H}_{3} \mathrm{O}\right)_{2} \mathrm{PS}_{2}$} $\mathrm{Na}(\mathbf{L} 2)$ & 100 & 0.0 \\
\hline & 500 & 0.0 \\
\hline & 1000 & 0.0 \\
\hline \multirow{3}{*}{$\left(3,4-\left(\mathrm{CH}_{3}\right)_{2} \mathrm{C}_{6} \mathrm{H}_{3} \mathrm{O}\right)_{2} \mathrm{PS}_{2}$} $\mathrm{Na}(\mathbf{L} \mathbf{3})$ & 100 & 0.0 \\
\hline & 500 & 0.0 \\
\hline & 1000 & 0.0 \\
\hline \multirow{3}{*}{$\left(3,5-\left(\mathrm{CH}_{3}\right)_{2} \mathrm{C}_{6} \mathrm{H}_{3} \mathrm{O}\right)_{2} \mathrm{PS}_{2}$} $\mathrm{Na}(\mathbf{L} \mathbf{4})$ & 100 & 0.0 \\
\hline & 500 & 0.0 \\
\hline & 1000 & 0.0 \\
\hline \multirow{3}{*}[\{2,4-(\mathrm{CH}_{3})_{2}\mathrm{C}_{6}\mathrm{H}_{3}\mathrm{O}\}_{2}\mathrm{PS}_{2}]{$_{3} \mathrm{Bi}(\mathbf{1})$} & 100 & 0.6 \\
\hline & 500 & 0.8 \\
\hline & 1000 & 1.0 \\
\hline \multirow{3}{*}[\{2,5-(\mathrm{CH}_{3})_{2}\mathrm{C}_{6}\mathrm{H}_{3}\mathrm{O}\}_{2}\mathrm{PS}_{2}]{$_{3} \mathrm{Bi}(2)$} & 100 & 1.1 \\
\hline & 500 & 1.3 \\
\hline & 1000 & 1.6 \\
\hline \multirow{3}{*}[\{3,4-(\mathrm{CH}_{3})_{2}\mathrm{C}_{6}\mathrm{H}_{3}\mathrm{O}\}_{2}\mathrm{PS}_{2}]{$_{3} \mathrm{Bi}(3)$} & 100 & 0.8 \\
\hline & 500 & 0.9 \\
\hline & 1000 & 1.2 \\
\hline \multirow{3}{*}[\{3,5-(\mathrm{CH}_{3})_{2}\mathrm{C}_{6}\mathrm{H}_{3}\mathrm{O}\}_{2}\mathrm{PS}_{2}]{$_{3} \mathrm{Bi}(4)$} & 100 & 1.1 \\
\hline & 500 & 1.3 \\
\hline & 1000 & 1.6 \\
\hline
\end{tabular}

\section{Conclusion}

Four new complexes of $\mathrm{Bi}(\mathrm{III})$ with disubstituted diphenyl dithiophosphate ligands have been isolated and characterized by IR and NMR $\left({ }^{1} \mathrm{H},{ }^{13} \mathrm{C}\right.$ and $\left.{ }^{31} \mathrm{P}\right)$ spectroscopy. The molecular structure of complex 4 was determi- 
ned by single-crystal X-ray diffraction study and depicted that the diphenyldithiophosphate ions act as bidentate ligands coordinating to the bismuth atom through their two $\mathrm{S}$ atoms. Each forms a four-membered chelate ring in the equatorial plane having $\left[\mathrm{BiS}_{2}\right]$ unit. The structural analysis reveals that these monomeric complexes possess a distorted octahedral about the bismuth center. The bismuth complexes proved to be a potent antifungal agent as compared to the free dithiophosphate ligand.

\section{Supplementary Information}

CCDC 1547047 contains the supplementary crystallographic data for compound 4 . The data can be obtained free of charge via http://www.ccdc.cam.ac.uk/conts/retrieving.html, or from the Cambridge Crystallographic Data Centre, 12 Union Road, Cambridge CB2 1EZ, UK; fax: (+44) 1223-336-033; or e-mail:deposit @ ccdc.cam.ac.uk.

\section{Acknowledgements}

The authors are grateful to the NMR laboratory Department of Chemistry, University of Jammu, Jammu, for providing the spectral facilities. The authors are grateful to Professor Geeta Hundal, Department of Chemistry, Guru Nanak Dev University, Amritsar, India, for her valuable suggestions.

\section{References}

1. O. C. Monteri, T. Trindade, J. H. Park, P, O’Brien, Chem. Vap. Dep. 2000, 6, 230-232.

2. Y. W. Koh, C. S. Lai, A. Y. Du, E. R. T. Tiekink, K. P. Loh, Chem. Mater. 2003, 15, 4544-4554. https://doi.org/10.1021/cm021813k

3. A. Gupta, R. K. Sharma, R. Bohra, V. K. Jain, J. E. Drake, M. B. Hursthouse, M. E. Light, J. Organomet. Chem. 2003, 678, 122-127. https://doi.org/10.1016/S0022-328X(03)00435-2

4. M. Kimura, A. Iwata, M. Itoh, K. Yamada, T. Kimura, N. Sugiura, M. Ishida, S. Kato, Helv. Chem. Acta 2006, 89, 747783. https://doi.org/10.1002/hlca.200690070

5. W. Lou, M. Chen, X. Wang, W. Liu, Chem. Mater. 2007, 19, 872-878. https://doi.org/10.1021/cm062549o

6. K. R. Chaudhari, A. Wadawale, S. Ghoshal, S. M. Chopade, V. S. Sagoria, V. K. Jain, Inorg. Chim. Acta 2009, 362, 18191824. https://doi.org/10.1016/j.ica.2008.08.022

7. D. W. Zhang, W. T. Chen, Y. F. Wang, Luminescence 2017, 32, 201-205. https://doi.org/10.1002/bio.3168

8. W. T. Chen, J. G. Huang, X. G. Yi, Acta Chim. Slov. 2016, 63, 899-904.

https://doi.org/10.17344/acsi.2016.2897

9. N. Yang, H. Sun, Coord. Chem. Rev. 2007, 251, 2354-2366. https://doi.org/10.1016/j.ccr.2007.03.003

10. A. Luqman, V. L. Blair, R. Brammananth, P. K. Crellin, R. L. Coppel, P. C. Andrews, Chem. Eur. J. 2014, 20, 1436214377. https://doi.org/10.1002/chem.201404109

11. L. Agocs, G. G. Briand, N. Burford, M. D. Eelman, N. Aumeerally, D. MacKay, K. N. Robertson, T. S. Cameron, Can. J. Chem. 2003, 81, 632-637. https://doi.org/10.1139/v03-054

12. R. Mohan, Nat. Chem. 2010, 2, 336-336. https://doi.org/10.1038/nchem.609

13. O. Rohr, Ind. Lubr. Tribol. 2002, 54, 153-164. https://doi.org/10.1108/00368790210431709

14. G. G. Briand, N. Burford, Chem. Rev. 1999, 99, 2601-2657. https://doi.org/10.1021/cr980425s

15. H. Maeda, Y. Tamaka, M. Fukutomi, T. Asano, Jpn. J. Appl. Phys. 1988, 27, L209-L210. https://doi.org/10.1143/JJAP.27.L209

16. T. Asaka, Y. Okazawa, T. Hirayama, K. Tachikawa, Jpn. J.Appl. Phys. 1990, 29, L280-L283. https://doi.org/10.1143/JJAP.29.L280

17. S. Katayama, M. Sekine, J. Mater. Res. 1991, 6, 36-41. https://doi.org/10.1557/JMR.1991.0036

18. B. A. Vaarstra, J. C. Huffman, W. E. Streib, K. G. Caulton, Inorg. Chem. 1991, 30, 3068-3072. https://doi.org/10.1021/ic00015a024

19. R. D. Rogers, A. H. Bond, S. Aguinaga, J. Am. Chem. Soc. 1992, 114, 2960-2967. https://doi.org/10.1021/ja00034a031

20. R. D. Rogers, A. H. Bond, S. Aguinaga, A. Reyes, J. Am. Chem. Soc. 1992, 114, 2967-2977. https://doi.org/10.1021/ja00034a032

21. S. R. Breeze, S. Wang, L. K. Thompson, Inorg. Chim. Acta 1996, 250, 163-171. https://doi.org/10.1016/S0020-1693(96)05223-1

22. E. Moya, L. Contreras, C. Zaldo, J. Opt. Soc. Am. 1988, B5, 1737-1742. https://doi.org/10.1364/JOSAB.5.001737

23. S. Wang, D. B. Mitzi, G. A. Landrum, H. Genin, R. Hoffmann, J. Am. Chem. Soc. 1997, 119, 724-732. https://doi.org/10.1021/ja961753h

24. P. Majewski, Adv. Mater. 1994, 6, 460-469. https://doi.org/10.1002/adma.19940060604

25. J. F. Scott, F. M. Ross, C. A. Paz de Araujo, M. C. Scott, M. Huffman, Mater. Res. Soc. Bull. 1996, 21, 33-39. https://doi.org/10.1557/S0883769400035892

26. A. Ekstrand, M. Nygren, G. Westin, J. Sol-Gel Sci. Technol. 1997, 8, 697-701.

27. F. Soares-Carvalho, P. Thomas, J. P. Mercurio, B. Frit, S. Parola, J. Sol-Gel Sci. Technol. 1997, 8, 759-763.

28. L. O. Rosik, U. S. Patent, Mallinckrodt Medical. Inc. 1995, A61B 005/055.

29. C. Coin, T. Zevaco, E. Dunach, M. Postel, Bull. Soc. Chim. Fr. 1996, 133, 913-918.

30. J. L. Lambert, P. Midolo, Aliment Pharmacol. Ther. 1997, 11, 27-33. https://doi.org/10.1046/j.1365-2036.11.s1.13.x

31. P. J. Sadler, H. Sun, J. Chem. Soc., Dalton Trans. 1995, 
1395-1401. https://doi.org/10.1039/dt9950001395

32. E. Asato, K. Katsura, M. Mikuriya, U. Turpeinen, I. Mutikainen, J. Reedijk, Inorg. Chem. 1995, 34, 2447-2454. https://doi.org/10.1021/ic00113a028

33. S. L. Gorbach, Gastroenterology 1990, 99, 863-875. https://doi.org/10.1016/0016-5085(90)90983-8

34. X. Wang, X. Zhang, J. Lin, J. Chen, Q. Xu, Z. Guo, J. Chem. Soc., Dalton Trans. 2003, 2379-2380. https://doi.org/10.1039/b305290g

35. P. Köpf-Maier, T. Klapötke, Inorg. Chim. Acta 1988, 152, 49-52. https://doi.org/10.1016/S0020-1693(00)90730-8

36. D. E. Mahony, S. Lim-Morrison, L. Bryden, G. Faulkner, P. S. Hoffman, L. Agocs, G. G. Briand, N. Burford, H. Maguire, Antimicrob. Agents Chemother. 1999, 43, 582-588.

37. R. Khajuria, S. Kumar, A. Syed, G. Kour, S. Anthal, V. K. Gupta, R. Kant, S. K. Pandey, J. Coord. Chem. 2014, 67, 2925-2941. https://doi.org/10.1080/00958972.2014.958473

38. S. Kumar, R. Khajuria, V. K. Gupta, R. Kant, S. K. Pandey, Polyhedron 2014, 72, 140-146. https://doi.org/10.1016/j.poly.2014.01.036

39. A. Syed, R. Khajuria, S. Kumar, A. K. Jassal, M. S. Hundal, S. K. Pandey, Acta Chim. Slov. 2014, 61, 866-874.

40. S. Kumar, R. Khajuria, A. K. Jassal, G. Hundal, M. S. Hundal, S. K. Pandey, Acta Cryst. 2014, B70, 761-767. http://dx.doi.org/10.1107/S2052520614014966

41. S. Kumar, R. Khajuria, A. Syed, A. K. Jassal, L. K. Rana, G. Hundal, S. K. Pandey, Monatsh. Chem. 2016, 147, 10371043. https://doi.org/10.1007/s00706-015-1569-6

42. S. Kumar, R. Khajuria, A. Syed, V. K. Gupta, R. Kant, S. K. Pandey, Transit. Met. Chem. 2015, 40, 519-523.

43. S. Kumar, S. Andotra, M. Kour, V. K. Gupta, R. Kant, S. K. Pandey, Crystallogr. Rep. 2016, 61, 810-814.
https://doi.org/10.1134/S1063774516050126

44. S. Maheshwari, J. E. Drake, K. Kori, M. E. Light, R. Ratnani, Polyhedron 2009, 28, 689-694. https://doi.org/10.1016/j.poly.2008.12.017

45. S. L. Lawton, C. J. Fuhrmeister, R. G. Haas, C. S. Jarman, F. G. Lohmeyer, Inorg. Chem. 1974, 13, 135-143. https://doi.org/10.1021/ic50131a026

46. M. J. Begley, D. B. Sowerby, I. Haiduc, J. Chem. Soc. Dalton Trans. 1987, 145-150. https://doi.org/10.1039/dt9870000145

47. D. Bryan Sowerby, I. Haiduc, J. Chem. Soc. Dalton Trans. 1987, 1257-1259. https://doi.org/10.1039/DT9870001257

48. F. T. Edelmann, M. Noltimeyer, I. Haiduc, C. Silvestru, R. Cea-Olivares, Polyhedron 1994, 13, 547-552. https://doi.org/10.1016/S0277-5387(00)84730-0

49. G. Svensson, J. Albertsson, Acta Chem. Scand. 1989, 43, 511-517. https://doi.org/10.3891/acta.chem.scand.43-0511

50. B. F. Hoskins, E. R. T. Tiekink, G. Winter, Inorg. Chim. Acta 1984, 81, L33-34. https://doi.org/10.1016/S0020-1693(00)88725-3

51. C. L. Raston, A. H. White, J. Chem. Soc. Dalton Trans. 1976, 791-794. https://doi.org/10.1039/dt9760000791

52. A. I. Vogel Quantitative, Inorganic Analysis, $3^{\text {rd }}$ Edn, Longmans, London, 1961.

53. M. A. Neelakantan, M. Esakkiammal, S. S. Mariappan, J. Dharmaraja, T. Jeyakumar, Indian J. Pharm. Sci. 2010, 72, 216-222. https://doi.org/10.4103/0250-474X.65015

54. C. Glidewell, Inorg. Chim. Acta 1977, 25, 159-163. https://doi.org/10.1016/S0020-1693(00)95706-2

55. M. Iglesias, C. D. Pino, S. M. Carrera, Polyhedron 1989, 8 , 483-489. https://doi.org/10.1016/S0277-5387(00)80746-9

\section{Povzetek}

Predstavljeni so štirje kompleksi s splošno formula $\left[\left\{(\mathrm{ArO})_{2} \mathrm{PS}_{2}\right\}_{3} \mathrm{Bi}\right](\mathbf{1 - 4})$, kjer je $\mathrm{Ar}=2,4-\left(\mathrm{CH}_{3}\right)_{2} \mathrm{C}_{6} \mathrm{H}_{3}, 2,5$ $\left(\mathrm{CH}_{3}\right)_{2} \mathrm{C}_{6} \mathrm{H}_{3}, 3,4-\left(\mathrm{CH}_{3}\right)_{2} \mathrm{C}_{6} \mathrm{H}_{3}$ in 3,5- $\left(\mathrm{CH}_{3}\right)_{2} \mathrm{C}_{6} \mathrm{H}_{3}$. Reakcija $\left[(\mathrm{ArO})_{2} \mathrm{PS}_{2} \mathrm{Na}\right]$ z Bi $\left(\mathrm{NO}_{3}\right)_{3} \cdot 5 \mathrm{H}_{2} \mathrm{O}$ v molskem razmerju 3:1 v toluenu vodi do nastanka kompleksov [ $\left.\left\{(\mathrm{ArO})_{2} \mathrm{PS}_{2}\right\}_{3} \mathrm{Bi}\right]$. Navedeni sintetizirani kompleksi so bili okarakterizirani z elementno analizo, FT-IR in NMR spektroskopijo $\left({ }^{1} \mathrm{H},{ }^{13} \mathrm{C} \text { in }{ }^{31} \mathrm{P} \text { NMR). Kristalna struktura }\left[\left\{\left(3,5-\mathrm{CH}_{3}\right)_{2} \mathrm{C}_{6} \mathrm{H}_{3} \mathrm{O}\right\}_{2} \mathrm{PS}\right]_{2}\right]_{3} \mathrm{Bi}$ (4) je bila določena s pomočjo rentgenske difrakcije. Spojina kristalizira v monoklinski $P 2_{1} / c$ prostorski skupini, $\mathrm{Bi}(\mathrm{III})$ center je obdan s šestimi žveplovimi atomi treh kelatnih difenil ditiofosfatnih ligandov v obliki popačenega oktaedra. Testiranje teh kompleksov proti Pencillium chrysogenum je dalo pozitivne rezultate. 